\title{
Determinants of repeated pregnancy among HIV-positive women on anti retroviral treatments at the public health facilities, in Gedeo zone, South Ethiopia: Unmatched case-control study
}

\author{
Yosef Lelamo $^{\mathrm{a}}$, Atnafu Adem ${ }^{\mathrm{b}}$, Azmach Dache $^{\mathrm{c}, *}$, Aregahegn Dona ${ }^{\mathrm{c}}$ \\ ${ }^{a}$ Aleta Chucko District Health, Sidama Regional State, Ethiopia \\ ${ }^{\mathrm{b}}$ Loka Abaya District Health, Sidama Regional State, Ethiopia \\ ${ }^{\mathrm{c}}$ Social and Population Health Department, Yirgalem Hospital Medical College, Yirgalem Sidama, Ethiopia
}

\section{A R T I C L E I N F O}

\section{Keywords:}

Repeated pregnancy

Determinants

Gedeo zone

Ethiopia

\begin{abstract}
A B S T R A C T
Background: The desire of HIV-infected woman to have children in the future has significant implications for the transmission of HIV to sexual partners and newborn. This study aimed to determine the determinants of repeated Pregnancy among HIV-positive women on Anti retroviral Treatments, at the public health facility, in Gedeo Zone, South Ethiopia.

Methods: An unmatched case-control study was conducted from February 10 to April 27, 2020, among a total of 304 (76 cases and 228 controls) pregnant women. The participants were selected by randomly and data was collected using face-to-face interviewer-administered questionnaires, and entered using Epidata3.1 and analyzed by SPSS version 20. Bivariate logistic regression was used to select the candidate variables for the multivariable logistic regression with a $p$-value $<0.25$, and in the last multivariate logistic regression analysis was performed to assess determinant factors of repeated pregnancy in adjusted odds ratio with a p-value $<0.05$, at $95 \%$ confidence level were declared statistically significant.

Results: A total of 304 pregnant mothers responded resulting in a response rate of $97.4 \%$. Determinants which were found to be associated with repeated pregnancy were history of abortion, low educational attainment, 30-43years of age, being employed, and urban residence.

Conclusions: The results of the current study suggest that repeated pregnancies were more common among women who had a history of abortion and low educational attainment. Health practitioners of the Gedeo zone should give particular attention to prevent abortion and provide appropriate reproductive health services for those women.
\end{abstract}

\section{Introduction}

Globally, the human immune virus (HIV) and complications of childbearing (pregnancy) are the top causes of death among women of reproductive age. ${ }^{1}$ In the world $50 \%$ of people infected with HIV/AIDS were women and complications related to pregnancy, are the leading cause of death among women of reproductive age. ${ }^{2}$ In 2016 an Estimated 0.4 million women living with HIV and $77 \%$ of pregnant women with known HIV status, $69 \%$ received antiretroviral for prevention of HIV mother to child transmission (PMTCT) in Ethiopia. ${ }^{3,4}$ Many people living with HIV choose to have children and require safer conception services to support their goals while minimizing the risk of HIV transmission to partner and child. ${ }^{5}$
The magnitude of repeated pregnancy among HIV-positive women differs from country to country. According to a study conducted in different parts of world, it reveals that $9.2 \%, 26 \%, 32.4 \%, 17.6 \%$ were reported from Latin America \& the Caribbean, the United Kingdom (UK), Zimbabwe, and Kenya respectively. ${ }^{6-9}$

Based on a systematic review of 23 studies, 17 of which were done in sub-Saharan Africa, HIV-infected pregnant or post-partum women were estimated to have nearly eight times the risk of death than non-HIVinfected women. ${ }^{10}$ The majority of new HIV infections that occur in children worldwide were among children born to HIV-positive mothers, who acquire HIV infection from their mothers. ${ }^{11}$

Women with HIV infection undergo repeat pregnancies not because of ineffective contraception but as a result of the desire to have multiple

\footnotetext{
* Corresponding author.

E-mail address: dacheazm@gmail.com (A. Dache).
} 
children. But, the desire of HIV-infected women to have children in the future has significant implications for the transmission of HIV to sexual partners and newborn. ${ }^{12,13}$ HIV-positive individuals in Africa have additional considerations to take into account when deciding whether or not to have children. These include the possibility of passing HIV from mother to child and the likelihood that one or both parents could die before the child reaches adulthood. ${ }^{14}$

Anti retroviral treatment (ART) improves the health of mothers and these mothers may be motivated to have more children. ${ }^{15}$ Having an index pregnancy that did not result in a live birth was an important predictor of having a repeat pregnancy. ${ }^{16}$

In study conducted in Ethiopia, a substantial number of PLWHA wants to have a child currently or shortly and the number of children desired in the future ranges from 1 to $6 .{ }^{17}$ Even though it is their right to have children, women are discouraged from getting pregnant while on ART because giving birth to HIV-positive mother could result in HIV positive babies. If proper care for the mothers is not in place, maternal death due to complications related to HIV and pregnancy can be very high. The risk of mortality from TB or AIDS increased by 1.48-fold, 1.76fold, and 1.59-fold for one, two, and three more pregnancies compared to no full-term pregnancy. ${ }^{18,19}$ The incidence of pregnancy among women living with HIV in Ethiopia was reported being 49.2 per 1000 person-years. $^{20}$

Some studies conducted in Ethiopia, as the number of pregnancy increase, the risk of AIDS mortality increased ${ }^{10,21-24}$ and hospitalization during the index pregnancy or up to 6 months postpartum and for poor index pregnancy outcomes were associated with increased occurrence of repeat pregnancy. ${ }^{16}$

Efforts in Ethiopia that focus on healthcare providers counsel WLWH to wait until they have improved their immunologic status and physical health before considering having children. ${ }^{20}$ Joint United Nations Programme on HIV/AIDS (UNAIDS) recommends that HIV-positive women should be able to control their fertility and prevent HIV transmission perinatally if they decide to have children. ${ }^{25,26}$

Also, Ethiopia has achieved the MDG target by reducing HIV new infection by $90 \%$ and mortality by more than $50 \%$ among adults in the last decade. Currently, treatments given for pregnant woman on HIV, that prevent Viral transmission to fetus (option $\mathrm{B}+$ ) is being implemented in all regions of the country reaching a $97 \%$ target achievement at national level in 2014. Ethiopia has committed to reducing new adult HIV infections by $50 \%$ by 2020 and to ending AIDS as a public health threat by $2030 .^{27}$

Although there is the increased use of contraceptives by women living with HIV pregnancies still occur in Ethiopia. Therefore, this study aimed to determine the determinants of repeated pregnancy among women enrolled in the ART Program at the public health facility in Gedeo zone, Southern Ethiopia.

\section{Methods}

\subsection{Study area and design}

The study was conducted in the Gedeo Zone which is one of the 15 Zonal administration divisions of Southern Nations, Nationalities and Peoples (SNNP) regional state of Ethiopia. The zone is located in the Southern part of the region and is $371 \mathrm{~km}$ far from Addis Ababa, the capital city of Ethiopia, and $96 \mathrm{~km}$ from Hawassa city, the capital of SNNP regional state.

The Zone is bordered by Borena Zone of Oromia regional state of Ethiopia in the South and West, Sidama National Regional state of Ethiopia in the North, and Guji Zone of Oromia regional state in the East.

The zone covers a total area of $5890.2 \mathrm{sq}$. $\mathrm{km}$ and has 8 districts, 2 administration towns, and 133 rural and 17 urban kebeles (kebele is the smallest administration level in Ethiopia). According to the Gedeo zone health department report, currently, the zone has 1 referral hospital, 3 Primary hospitals, 38 health centers, 148 health posts, and 12 private and 4 non-governmental organizations (NGO) clinics.

Four hospitals and four health centers provide a comprehensive ART service in the zone. According to the Gedeo zone ART case team Health Management Information system (HMIS 2019) report, a total of 3597 adults PLWHIVs.

Among 3597of 629 were pre-ART (370 female and 259 male). Among 3597of 2968 currently on ART (1813 female and 1155 male). Of which, while 2922 (1790 female and 1132 male) of them were in the first-line regimen. Only 46 ( 23 female, 23 male) were in the second-line regimen. Among these subjects, while 1892 (135 pre-ART and 537 ART exposed) were enrolled in the ART clinics of health centers, the remaining 2807 (412 pre-ART and 2395 ART exposed) of them were enrolled in the hospitals found in the zone. An unmatched facility-based case-control study design was conducted from February 10 to April 27, 2020.

\subsection{Study population, sample size determination, and sampling procedure}

HIV-positive pregnant women on prevention of HIV from mother to child transmission (PMTCT) care who have repeated pregnancy after her index child pregnancy since HIV/AIDS diagnosis who was selected by randomly from eight public health facilities, during the study period were study population for cases.

HIV-positive pregnant women on PMTCT care who have only index pregnancy since HIV/AIDS diagnosis who was selected randomly from eight public health facilities, during the study period were the study population for controls.

All women who have repeated pregnancy after HIV diagnosis who was selected randomly and volunteer to provide information during the study period were included in the study as cases. All women who have an index or first pregnancy after HIV diagnosis who was selected randomly and volunteer to provide information during the study period were included in the study as controls. Women with severe illness unable to provide information for both cases and controls during the data collection were excluded from the study.

The sample size was computed for the current study using a formula for two population proportions formula for unmatched case-control study $^{28-30}$ and calculated by Epi info Version 3.03 statistical software packages by considering the following information OR: 0.45 , CI: $95 \%$, Power of the study: $80 \%$ and the ratio of cases to controls of $1: 3$ With adjustment for $10 \%$ non-response rate. The final sample size was 312 , (78 cases, and 234 controls).

The facility that provides comprehensive ART service which is Dilla University referral hospital, Yirgachefe primary hospital, Bule primary Hospital, Gedeb primary hospital, Wonago health center Dilla health center, Chelelekitu health center, and Garse health center were selected to get an adequate number of study participants. To allocate proportional sample size for each facility the numbers of pregnancy in each PMTCT facility were taken as a reference. They are grouped as cases or controls based on a number of pregnancies. Both cases and controls were selected randomly. Which means a list of all repeated and first pregnancy was identified through the registry and cross-checked by midwife by asking a woman whether repeated or first pregnancy based on the operational definition. Then sampling frame was developed for one case and three controls were interviewed until the allocated sample is achieved at each facility.

\subsection{Variables of the study}

Repeated pregnancy was the dependent variable and sociodemographic characteristics: Age, Place of residence, educational level, marital status, Occupational status, religion, family sizes; and socio-economic characteristics; Clinical characteristics of women at enrollments: CD4 count, WHO staging, Functional status of women on ART; Past obstetric history: Parity, gravidity, Poor pregnancy outcomes, death of the pervious child, hospitalization during index pregnancy or 
postpartum; health service utilization and behavioral information: Prior use of family planning and having talked to a partner about family planning (FP) use were independent variables.

\subsection{Operational definition}

Repeated pregnancy: it is subsequent or second pregnancy after HIV care enrollments.

Index pregnancy: First pregnancy after HIV cares enrollments. Hospitalization during index pregnancy: Any history of hospital admission during her first pregnancy or delivery of a child for pregnancy reason. Functional status: Working: able to perform usual work in or out of the house Ambulatory: able to perform activities of daily living. Bedridden: not able to perform activities of daily living.

\subsection{Data collection and tools}

Face face interview using a pre-tested and structured questionnaire was used to collect the data. Tools were prepared from different published work of literature to extract the relevant data from the individual participants. The questionnaire was developed in English based on objectives to be addressed and variables included in the questionnaires were socio-demographic characteristics, wealth status, clinical characteristics, WHO staging, functional status of women on ART, and hospitalizations during the index pregnancy.

Two data collectors who have a Bachelor of Science in midwifery were recruited. In addition to these data collectors, one health informants (data clerk person) and two runners working in the card room were also recruited to collect the individual charts using the medical record number (MRN) and replace them in the card room respectively.

Two-day theoretical and practical training was given to the data collectors and runners. Then, the midwives and health information trained personnel (HIT) filled the checklist from the patients' individual chart and then midwife collects data from individual caretaker after validating her for a number of pregnancy based on the operational definition.

The principal investigator was strictly following for each activity on a daily basis to ensure the completeness of the questionnaire and checklist, to give further clarification and support for data collectors. Since the individual chart is not allowed to be brought out of the hospital; data collectors were health professionals, and they have worn a white coat to blend into the service delivery. The cards were not exposed to other than the members of the data collecting group.

\subsection{Data quality assurance and statistical analysis}

An English version questionnaire was translated into Gedeoffa (local language) and then back to English to check its consistency. The data collection tools were pre-tested in the Aleta-chuko primary hospital which was not the same place as study the area, with the $5 \%$ of sample. Its consistency checked and the correction was made accordingly before the actual data collection. The principal investigator rechecks completeness of the data during submission. For better data quality, patients' individual chart was cross-checked with PMTCT/delivery room registration book, if there missed data.

Data was entered by using Epidata3.1 version and exported to SPSS version 20 for analysis. Descriptive statistics were used to describe the data of the study unit. Bivariate logistic regression was used to see the association between one explanatory variable and the outcome variable at $p$-value $<0.25$. The wealth status of the study participants analyzed by Principal Component analysis (PC). Multivariable logistic regression analysis was performed to predict factors that affect the dependent variable. Those variables that have AOR at $95 \%$ of CI with a p-value $<$ 0.05 were declared statistically significant in multivariable analysis. Hosmer- Lemeshow test was used to test the model fitness and it was 0.889 which was not significant.

\section{Results}

\subsection{Socio-demographic characteristics of the study participants on ART}

A total of 304 (76 cases and 228 controls) pregnant mothers responded resulting in a response rate of $97.4 \%$. The mean age of cases 25.5 years (SD: \pm 3.6 ) was less than that of the controls 28 years (SD: \pm 5). With regards to the participant's residence, the majority of cases 58 (76.3\%) were from rural residents, while $158(69.3 \%)$ of the controls were from urban areas. Educationally, in half of the cases $39(51 \%)$ and a quarter of controls 61 (26\%) attended elementary school (1-8 grade).

Respondent's wealth status, $12(37.5 \%)$ of cases and half of controls 45 (49.5\%) were from the poorer category. Half of the cases $37(48.7 \%)$ and $131(43.2 \%)$ of controls follow protestant religion. With regards to their occupation, $54(71.1 \%)$ of cases and the majority of controls 193 (84.6\%) were unemployed. More than quarter $22(28.9 \%)$ of cases and 35 (15.4\%) of controls were employed (Table 1$)$.

\subsection{Health service utilization behavioral information of the woman}

Sixty-six 66 (86.8\%) of cases and $192(84.2 \%)$ of the controls have discussed family planning with a partner. Two hundred and ninthly four (96.7\%) which were 70 (92.1\%) of cases and 224 (98.2\%) of controls was in Prior use of family planning. Two hundred and seventy-seven (91.1\%) of participants which was 68 (89.5\%) of cases and 209 (91.7\%) of controls had no history of hospitalization during pregnancy

Table 1

Socio-demographic characteristics of the study participants at public health facilities, in Gedeo zone Southern, Ethiopia, 2020.

\begin{tabular}{|c|c|c|c|c|c|}
\hline Variables & & $\begin{array}{l}\text { Case, } \mathrm{N} \\
(\%)\end{array}$ & $\begin{array}{l}\text { Control, } \\
\mathrm{N}(\%)\end{array}$ & $\begin{array}{l}\mathrm{N},(\%) \\
\text { Total }\end{array}$ & $\begin{array}{l}\text { Chi- } \\
\text { square } \\
\text { (df) }\end{array}$ \\
\hline \multirow[t]{3}{*}{$\begin{array}{l}\text { Age of } \\
\text { Respondents }\end{array}$} & 20-24years & $\begin{array}{l}42 \\
(55.2 \%)\end{array}$ & $\begin{array}{l}74 \\
(32.5 \%)\end{array}$ & $\begin{array}{l}116 \\
(38.2 \%)\end{array}$ & $17.2(2)$ \\
\hline & $25-29$ years & $\begin{array}{l}23 \\
(30.3 \%)\end{array}$ & $\begin{array}{l}68 \\
(29.8 \%)\end{array}$ & $\begin{array}{l}91 \\
(29.9 \%)\end{array}$ & \\
\hline & 30-43years & $\begin{array}{l}11 \\
(14.5 \%)\end{array}$ & $\begin{array}{l}86 \\
(37.7 \%)\end{array}$ & $\begin{array}{l}97 \\
(31.9 \%)\end{array}$ & \\
\hline \multirow[t]{2}{*}{ Residence } & Rural & $\begin{array}{l}58 \\
(76.3 \%)\end{array}$ & $\begin{array}{l}70 \\
(30.7 \%)\end{array}$ & $\begin{array}{l}128 \\
(42.1 \%)\end{array}$ & $48.6(1)$ \\
\hline & Urban & $\begin{array}{l}18 \\
(23.7 \%)\end{array}$ & $\begin{array}{l}158 \\
(69.3 \%)\end{array}$ & $\begin{array}{l}176 \\
(57.9 \%)\end{array}$ & \\
\hline \multirow{4}{*}{$\begin{array}{l}\text { Educational } \\
\text { status of the } \\
\text { respondents }\end{array}$} & $\begin{array}{l}\text { Can't read } \\
\text { and write }\end{array}$ & $\begin{array}{l}9 \\
(11.8 \%)\end{array}$ & $\begin{array}{l}49 \\
(21.5 \%)\end{array}$ & $\begin{array}{l}58 \\
(19.1 \%)\end{array}$ & 17.1 (3) \\
\hline & $\begin{array}{l}\text { Read and } \\
\text { write }\end{array}$ & $\begin{array}{l}19 \\
(25.0 \%)\end{array}$ & $\begin{array}{l}65 \\
(28.5 \%)\end{array}$ & $\begin{array}{l}84 \\
(27.6 \%)\end{array}$ & \\
\hline & $1-8$ & $\begin{array}{l}39 \\
(51.4 \%)\end{array}$ & $\begin{array}{l}61 \\
(26.8 \%)\end{array}$ & $\begin{array}{l}100 \\
(32.9 \%)\end{array}$ & \\
\hline & $\begin{array}{l}\text { High school } \\
\text { and above }\end{array}$ & $\begin{array}{l}9 \\
(11.8 \%)\end{array}$ & $\begin{array}{l}53 \\
(23.2 \%)\end{array}$ & $\begin{array}{l}62 \\
(20.4 \%)\end{array}$ & \\
\hline \multirow[t]{2}{*}{$\begin{array}{l}\text { Occupational } \\
\text { status }\end{array}$} & Employed & $\begin{array}{l}6 \\
(7.9 \%)\end{array}$ & $\begin{array}{l}64 \\
(28.1 \%)\end{array}$ & $\begin{array}{l}70 \\
(23.0 \%)\end{array}$ & $13(1)$ \\
\hline & Unemployed & $\begin{array}{l}70 \\
(92.1 \%)\end{array}$ & $\begin{array}{l}164 \\
(71.9 \%)\end{array}$ & $\begin{array}{l}234 \\
(77.0 \%)\end{array}$ & \\
\hline \multirow[t]{5}{*}{ Religion } & Orthodox & $\begin{array}{l}16 \\
(21.1 \%)\end{array}$ & $\begin{array}{l}37 \\
(16.2 \%)\end{array}$ & $\begin{array}{l}53 \\
(17.4 \%)\end{array}$ & $2.2(4)$ \\
\hline & Muslim & $\begin{array}{l}11 \\
(14.5 \%)\end{array}$ & $\begin{array}{l}23 \\
(10.1 \% \\
\%)\end{array}$ & $\begin{array}{l}34 \\
(11.2 \%)\end{array}$ & \\
\hline & Protestant & $\begin{array}{l}37 \\
(48.7 \%\end{array}$ & $\begin{array}{l}131 \\
(57.5 \%)\end{array}$ & $\begin{array}{l}168 \\
(55.3 \%)\end{array}$ & \\
\hline & Catholic & $\begin{array}{l}10 \\
(13.2 \%)\end{array}$ & $\begin{array}{l}23 \\
(10.1 \%)\end{array}$ & $\begin{array}{l}33 \\
(10.8 \%)\end{array}$ & \\
\hline & Others & $\begin{array}{l}2 \\
(2.5 \%)\end{array}$ & $\begin{array}{l}14 \\
(6.1 \%)\end{array}$ & $\begin{array}{l}16 \\
(5.3 \%)\end{array}$ & \\
\hline \multirow[t]{3}{*}{$\begin{array}{l}\text { Wealth } \\
\text { indicator }\end{array}$} & Poor & $\begin{array}{l}29 \\
(38.3 \%)\end{array}$ & $\begin{array}{l}113 \\
(49.5 \%)\end{array}$ & $\begin{array}{l}142 \\
(46.7 \%)\end{array}$ & $1.7(2)$ \\
\hline & Middle & $\begin{array}{l}27 \\
(35.5 \%)\end{array}$ & $\begin{array}{l}72 \\
(31.5 \%)\end{array}$ & $\begin{array}{l}99 \\
(32.6 \%)\end{array}$ & \\
\hline & Richer & $\begin{array}{l}20 \\
(26.2 \%)\end{array}$ & $\begin{array}{l}43 \\
(18.1 \%)\end{array}$ & $\begin{array}{l}63 \\
(20.7 \%)\end{array}$ & \\
\hline
\end{tabular}


or postpartum periods (Table.2).

\subsection{Past obstetric history and clinical characteristics during care enrollment of HIV positive mothers on ART}

Two hundred and sixty-four mothers (86.6\%) had one or fewer children at care enrollment (89.5\%) of cases and (86.0\%) of controls). Fifty-nine (19.4\%) of mothers had a history of abortion which means about $34.2 \%$ among cases and $14.5 \%$ among controls. History of child death was documented in $9.2 \%$ of the study subjects $(11.8 \%$ of cases and $8.3 \%$ of controls). Eighty-nine (29.3\%) had CD4 count 200-350 cell/ mm3at enrollment, $22(28.9 \%)$ of cases and $67(29.4 \%)$ of controls (Table 3).

\subsection{Determinants of repeated pregnancy}

In bivariable logistic regression analysis variables like CD4 count at enrolments, history of abortion, educational status, age, residences, CD4 counts at care enrollments, and employment status were associated with repeated pregnancy.

In multivariate logistic regression analysis, the risk of becoming repeated pregnancy was lower among 30-43 aged women compared to $20-24$ years $[\mathrm{AOR}=0.23,95 \% \mathrm{CI}(0.10,0.56)]$. The risk of having repeated pregnancy was lower among urban women compared to rural HIV-infected pregnant women $[\mathrm{AOR}=0.1 \mathrm{CI}(0.05,0.22)]$. Mothers, who had low educational attainment, had 4.6 times more likely to have repeated pregnancy compared to those who had attended higher education $[\mathrm{AOR}=4.6,95 \%$ CI: $(1.69,12.67)]$. Repeated pregnancy was lower for women who had been employed compared to the women who had not been employed [AOR: $0.18,95 \%$ CI: $(0.06,0.52)]$. Mothers who had a history of abortion were about 4.75 times more likely to have repeated pregnancy compared to the mother who had no abortion [AOR $=4.75,95 \%$ CI: $(2.13,10.57$ ] (Table 4).

\section{Discussion}

This study shows that HIV-positive mothers who had repeated pregnancy were on average younger than HIV- positive women who had index pregnancies after HIV care enrollment. Such findings may be due to a higher desire for children among the younger women.

A Study conducted in southeast Brazil support the finding, they reported that a higher pregnancy risk among women younger than 30 and younger age was a strong pregnancy predictor. ${ }^{31}$ For Women whose age ranges from 30 to 43years, the risk of having repeat pregnancy was $77 \%$ lower compared to 20-24years. This is in agreement with studies conducted in Kenya. ${ }^{4}$ These observations are expected because women were generally most fertile between the ages of 20 and 24 years and as they get older the likelihood of getting pregnant declines and in 30-43 years

Table 2

Health service utilization characteristics of the woman on ART at public health facilities in Gedeo zone, Southern Ethiopia, 2020.

\begin{tabular}{|c|c|c|c|c|c|}
\hline Variables & & $\begin{array}{l}\text { Case, N } \\
(\%)\end{array}$ & $\begin{array}{l}\text { Control, } \\
\mathrm{N}(\%)\end{array}$ & $\begin{array}{l}\mathrm{N},(\%) \\
\text { Total }\end{array}$ & $\begin{array}{l}\text { Chi- } \\
\text { square } \\
\text { (df) }\end{array}$ \\
\hline \multirow[t]{2}{*}{$\begin{array}{l}\text { Discussed about family } \\
\text { planning with partner }\end{array}$} & Yes & $\begin{array}{l}66 \\
(86.8 \%)\end{array}$ & $\begin{array}{l}192 \\
(84.2 \%)\end{array}$ & $\begin{array}{l}258 \\
(84.9 \%)\end{array}$ & $0.3(1)$ \\
\hline & No & $\begin{array}{l}10 \\
(13.2 \%)\end{array}$ & $\begin{array}{l}36 \\
(15.8 \%)\end{array}$ & $\begin{array}{l}46 \\
(15.1 \%)\end{array}$ & \\
\hline \multirow[t]{2}{*}{ Prior use of FP } & Yes & $\begin{array}{l}70 \\
(92.1 \%)\end{array}$ & $\begin{array}{l}224 \\
(98.2 \%)\end{array}$ & $\begin{array}{l}294 \\
(96.7 \%)\end{array}$ & $6.7(1)$ \\
\hline & No & $6(7.9 \%)$ & $4(1.8 \%)$ & $\begin{array}{l}10 \\
(3.3 \%)\end{array}$ & \\
\hline \multirow{2}{*}{$\begin{array}{l}\text { Hospitalization during } \\
\text { pregnancy or } \\
\text { postpartum period }\end{array}$} & Yes & $\begin{array}{l}8 \\
(10.5 \%)\end{array}$ & $19(8.3 \%)$ & $\begin{array}{l}27 \\
(8.9 \%)\end{array}$ & $0.33(1)$ \\
\hline & No & $\begin{array}{l}68 \\
(89.5 \%)\end{array}$ & $\begin{array}{l}209 \\
(91.7 \%)\end{array}$ & $\begin{array}{l}277 \\
(91.1 \%)\end{array}$ & \\
\hline
\end{tabular}

Table 3

Past obstetric history and clinical characteristics during care enrollment of HIV positive mothers on ART, at public health facilities in Gedeo zone, Southern Ethiopia, 2020.

\begin{tabular}{|c|c|c|c|c|c|}
\hline Variables & & $\begin{array}{l}\text { Case, } n \\
(\%)\end{array}$ & $\begin{array}{l}\text { Control, } \\
\text { n (\%) }\end{array}$ & $\begin{array}{l}\mathrm{n},(\%) \\
\text { Total }\end{array}$ & $\begin{array}{l}\text { Chi- } \\
\text { square } \\
\text { (df) }\end{array}$ \\
\hline \multirow{2}{*}{$\begin{array}{l}\text { Number of } \\
\text { children at } \\
\text { care } \\
\text { enrollment }\end{array}$} & $0-1$ & $\begin{array}{l}68 \\
(89.5 \%)\end{array}$ & $\begin{array}{l}196 \\
(86.0 \%)\end{array}$ & $\begin{array}{l}264 \\
(86.8 \%)\end{array}$ & \multirow[t]{2}{*}{0.61 (1) } \\
\hline & $\begin{array}{l}2 \text { and } \\
\text { above }\end{array}$ & $8(10.5 \%)$ & $\begin{array}{l}32 \\
(14.0 \%)\end{array}$ & $\begin{array}{l}40 \\
(13.2 \%)\end{array}$ & \\
\hline \multirow[t]{2}{*}{$\begin{array}{l}\text { History of } \\
\text { abortion }\end{array}$} & Yes & $\begin{array}{l}26 \\
(34.2 \%)\end{array}$ & $\begin{array}{l}33 \\
(14.5 \%)\end{array}$ & $\begin{array}{l}59 \\
(19.4 \%)\end{array}$ & \multirow[t]{2}{*}{$14.1(1)$} \\
\hline & No & $\begin{array}{l}50 \\
(65.8 \%)\end{array}$ & $\begin{array}{l}195 \\
(85.5 \%)\end{array}$ & $\begin{array}{l}245 \\
(80.6 \%\end{array}$ & \\
\hline \multirow[t]{2}{*}{$\begin{array}{r}\text { Number of } \\
\text { abortion }\end{array}$} & $0-1$ & $\begin{array}{l}64 \\
(84.2 \%)\end{array}$ & $\begin{array}{l}187 \\
(82.0 \%)\end{array}$ & $\begin{array}{l}251 \\
(82.6 \%)\end{array}$ & \multirow[t]{2}{*}{0.19 (1) } \\
\hline & $\begin{array}{l}2 \text { and } \\
\text { above }\end{array}$ & $\begin{array}{l}12 \\
(15.8 \%)\end{array}$ & $\begin{array}{l}41 \\
(18.0 \%)\end{array}$ & $\begin{array}{l}53 \\
(17.4 \%)\end{array}$ & \\
\hline \multirow{2}{*}{$\begin{array}{l}\text { History of child } \\
\text { death Since } \\
\text { HIV positive }\end{array}$} & Yes & $9(11.8 \%)$ & $\begin{array}{l}19 \\
(8.3 \%)\end{array}$ & $\begin{array}{l}28 \\
(9.2 \%)\end{array}$ & \multirow[t]{2}{*}{$0.84(1)$} \\
\hline & No & $\begin{array}{l}67 \\
(88.2 \%)\end{array}$ & $\begin{array}{l}209 \\
(91.7 \%)\end{array}$ & $\begin{array}{l}276 \\
(90.8 \%)\end{array}$ & \\
\hline \multirow[t]{2}{*}{$\begin{array}{l}\text { Number of child } \\
\text { Death }\end{array}$} & $0-1$ & $\begin{array}{l}63 \\
(82.9 \%)\end{array}$ & $\begin{array}{l}195 \\
(85.5 \%)\end{array}$ & $\begin{array}{l}258 \\
(84.9 \%)\end{array}$ & \multirow[t]{2}{*}{$0.3(1)$} \\
\hline & $\begin{array}{l}2 \text { and } \\
\text { above }\end{array}$ & $\begin{array}{l}13 \\
(17.1 \%)\end{array}$ & $\begin{array}{l}33 \\
(14.5 \%)\end{array}$ & $\begin{array}{l}46 \\
(15.1 \%)\end{array}$ & \\
\hline \multirow[t]{3}{*}{ Parity } & $0-1$ & $\begin{array}{l}31 \\
(40.6 \%)\end{array}$ & $\begin{array}{l}97 \\
(42.5 \%)\end{array}$ & $\begin{array}{l}128 \\
(42.1 \%)\end{array}$ & \multirow[t]{3}{*}{$0.57(2)$} \\
\hline & $2-3$ & $\begin{array}{l}29 \\
(38.0 \%)\end{array}$ & $\begin{array}{l}28 \\
(36.8 \%)\end{array}$ & $\begin{array}{l}117 \\
(38.5 \%)\end{array}$ & \\
\hline & $\begin{array}{l}4 \text { and } \\
\text { above }\end{array}$ & $\begin{array}{l}16 \\
(21.4 \%)\end{array}$ & $\begin{array}{l}42 \\
(18.4 \%)\end{array}$ & $\begin{array}{l}59 \\
(19.4 \%)\end{array}$ & \\
\hline \multirow[t]{3}{*}{$\begin{array}{l}\text { WHO Clinical } \\
\text { stage }\end{array}$} & $\begin{array}{l}\text { Clinical } \\
\text { stage } 1\end{array}$ & $\begin{array}{l}51 \\
(67.1 \%)\end{array}$ & $\begin{array}{l}167 \\
(73.2 \%)\end{array}$ & $\begin{array}{l}218 \\
(71.7 \%)\end{array}$ & \multirow[t]{3}{*}{$2.2(2)$} \\
\hline & $\begin{array}{l}\text { Clinical } \\
\text { stage } 2\end{array}$ & $\begin{array}{l}18 \\
(26.5 \%)\end{array}$ & $\begin{array}{l}50 \\
(21.9 \%)\end{array}$ & $\begin{array}{l}68 \\
(22.3 \%)\end{array}$ & \\
\hline & $\begin{array}{l}\text { Clinical } \\
\text { stage } 3\end{array}$ & $7(9.2 \%)$ & $\begin{array}{l}11 \\
(4.8 \%)\end{array}$ & $\begin{array}{l}18 \\
(5.9 \%)\end{array}$ & \\
\hline \multirow[t]{3}{*}{$\begin{array}{l}\text { CD4 counts at } \\
\text { Enrolments }\end{array}$} & $\begin{array}{l}\text { Less than } \\
200 \text { cell/ } \\
\mathrm{mm}^{3}\end{array}$ & $\begin{array}{l}29 \\
(38.2 \%)\end{array}$ & $\begin{array}{l}106 \\
(46.5 \%)\end{array}$ & $\begin{array}{l}135 \\
(44.4 \%)\end{array}$ & \multirow[t]{3}{*}{$2.5(2)$} \\
\hline & $\begin{array}{l}200-350 \\
\text { cell } / \mathrm{mm}^{3}\end{array}$ & $\begin{array}{l}22 \\
(28.9 \%)\end{array}$ & $\begin{array}{l}67 \\
(29.4 \%)\end{array}$ & $\begin{array}{l}89 \\
(29.3 \%)\end{array}$ & \\
\hline & $\begin{array}{l}\geq 350 \text { cell/ } \\
\mathrm{mm}^{3}\end{array}$ & $\begin{array}{l}25 \\
(232.9 \%)\end{array}$ & $\begin{array}{l}55 \\
(24.1 \%)\end{array}$ & $\begin{array}{l}80 \\
(26.3 \%)\end{array}$ & \\
\hline
\end{tabular}

period the desire of children might be decreasing. For women whose age ranges fell into 20-29 years had higher the desire for children. This finding supported by a case-control study by the desire for Children among HIV-Positive women in the Afar Region. ${ }^{6,32}$

Concerning past obstetric history, this study revealed that the odds of HIV-positive women with a history of abortion having repeated pregnancy were higher compared to those who had no history of abortions. This finding is consistent with the studies conducted in Zimbabwe and Latin America. ${ }^{6,16}$

Some kinds of literature suggested that women who are HIV-positive have a greater risk of abortion. ${ }^{33}$ This and our finding implies women with a history of abortion while HIV positive, Post-abortion care (PAC) is needed to provide treatment for complications caused by incomplete or spontaneous abortion and critical family planning counseling and services to prevent future unplanned pregnancies that may result in repeat abortions. It was supported by the finding from Sub-Saharan Africa have shown that the death of a child was associated with a higher desire to get pregnant and indicating that child loss is a powerful motivator to decide for repeated pregnancy. ${ }^{34,35}$

The other important risk factor for repeated pregnancy was the status of education. Mothers who have higher educational attainments had repeated pregnancy more likely compared to mothers who had low education attainments (1-8grade). This might be due to their lesser understanding of childbearing within the context of HIV positivity and they develop self-confidence how to care themselves during the 
Table 4

Determinants of repeated pregnancy mothers among HIV positive women in Gedeo zone at public health facilities in Gedeo zone, Southern Ethiopia, 2020.

\begin{tabular}{|c|c|c|c|c|c|c|}
\hline Variables & & Cases, n (\%) & Controls, n (\%) & COR 95\% CI & AOR 95\% CI & $\mathrm{P}$-value \\
\hline \multirow[t]{3}{*}{ Age of respondents } & 20-24years & $42(55.3 \%)$ & $74(32.5 \%)$ & 1 & 1 & 1 \\
\hline & $25-29$ years & $23(30.3 \%)$ & $68(29.8 \%)$ & $0.6(0.32 .-1.09)$ & $0.87(0.34-1.90)$ & 0.718 \\
\hline & 30-43years & $11(15.5 \%)$ & $86(37.7 \%)$ & $0.22(0.108-0.469)$ & $0.23(0.10-0.56)$ & $0.001^{* * *}$ \\
\hline \multirow[t]{4}{*}{ Educational status of respondents } & Can't read and write & $9(11.8 \%)$ & $49(21.5 \%)$ & 1 & 1 & 1 \\
\hline & Read and write & $19(25.0 \%)$ & $65(28.5 \%)$ & $1.6(0.66-3.82)$ & $1.06(0.36-3.13)$ & 0.91 \\
\hline & $1-8$ grade & $39(51.3 \%)$ & $61(26.8 \%)$ & $3.5(1.53-7.87)$ & $4.62(1.6-12.67)$ & $0.003^{* * *}$ \\
\hline & High school and above ( $\geq 9$ grade) & $9(11.8 \%)$ & $53(23.2 \%)$ & $0.92(0.34-2.51)$ & $1.3(0.38-4.50)$ & 0.65 \\
\hline \multirow[t]{2}{*}{ Residence } & Rural & $58(76.3 \%)$ & $70(30.7 \%)$ & 1 & 1 & 1 \\
\hline & Urban & $18(23.7 \%)$ & $158(69.3 \%)$ & $0.13(0.076-0.250)$ & $0.1(0.05-0.22)$ & $0.0001 * * *$ \\
\hline \multirow[t]{2}{*}{ Occupational status of respondents } & Unemployed & $70(92.1 \%)$ & $164(71.9 \%)$ & 1 & 1 & 1 \\
\hline & Employed & $6(7.9 \%)$ & $64(28.1 \%)$ & $0.22(0.091-0.531)$ & $0.18(0.06-0.52)$ & $0.001^{* * *}$ \\
\hline \multirow[t]{2}{*}{ History of abortion } & Yes & $26(34.2 \%)$ & $33(14.5 \%)$ & $3.0(1.68-5.60)$ & $4.75(2.13-10.57)$ & $0.001^{* * *}$ \\
\hline & No & $50(65.8 \%)$ & $195(85.5 \%)$ & 1 & 1 & 1 \\
\hline
\end{tabular}

COR = Crude Odds Ratio; AOR = Adjusted Odds Ratio; CI = Confidence level; *** = P-value $<0.05$.

pregnancy.

The risk of repeated pregnancy was $82 \%$ lower for women who had been employed comparing to the women who had not been employed. The possible justification of this finding might be due to the fact that in most circumstances in Ethiopia employed women are those with better educational status; line those women having better education may have a chance to access information from different types of media. There still exists a considerable knowledge gap regarding ART and there is the need to raise awareness. ${ }^{36}$

For women whose resident in the urban area to have repeated pregnancy was $90 \%$ lower compared to rural HIV infected pregnant women. It might be improved understanding about childbearing within HIV positive. It is also due to the fact that, in urban areas, the accessibility of quality family planning services was higher in the community and for mothers on ART in particular than rural and it might have a chance to access information from types of media. The strength of this study is since the principal investigator utilized primary data for analysis it may reduce documentation biases and the design being analytical approach. This Study is used a case-control study design and it relies often on recall or records for information on past exposures and is vulnerable to recall bias. Therefore, in this study, the possibility of recall bias since most data is based on patient's self-report.

\section{Conclusions}

This study found that repeated pregnancies were more common among HIV- infected women who had a history of abortion, low educational attainment but lower among 30-43years of age, employed, and urban women. Health Planners at Southern Ethiopia and Gedeo zone, particular attention to be given to the women who have diagnosed repeated pregnancy and health practitioners of Gedeo zone should give particular attention and provide appropriate reproductive health services for those women who are pregnant and treated with ART. Further research implication a prospective study on the predictors of repeated pregnancy among HIV-positive women while using ART drugs will demand attention.

\section{Ethics approval and consent to publication}

Prior to data collection appropriate ethical clearance and the supportive letter was obtained from Dilla University College of Medicine and Health Sciences Institutional Review Board (IRB) and oral informed consent was obtained from all parents. All methods were carried out in accordance with relevant guidelines and regulations Ethics approval and consent to participate.

\section{Consent for publication}

\section{Availability of data and materials}

All data are available within the manuscript and it will be upon reasonable request from the corresponding author.

\section{Competing interests}

The authors declare that they have no conflicts of interest.

\section{Fund}

No funding.

\section{Author contributions}

YL: involved in conceptualization, investigation, and formal analysis; AA: formally analysis and manuscript review; $A D$ participated in the design, data curation, and manuscript review; AD participated in draft preparation and critically revised the manuscript.

\section{Acknowledgements}

We would like to thank the data collectors and supervisors for their cooperation. We also sincerely appreciate Dilla University and my appreciation also goes to the Gedeo Zone health department. Finally, my appreciation also goes to all those health providers working in the ART/ PMTCT unit and clients for their willingness to participate in the study.

\section{References}

1 United Nations Programme on HIV/ADIS (UNAIDS). The Road to 90-90-90 (95-9595) Progress in HIV Prevention and Treatment Scale up in Sub-saharan Africa. 2019.

2 UNAIDS. The Road Progress in HIV Prevention and Treatment Scale up in Sub-saharan Africa. 2018.

3 UNAIDS. Gap Report People Left behind: Children and Pregnant Women Living with HI. 2014.

4 World Health Organization (WHO). The Global HIV/AIDS epidemic; 2019. Available at https://www.kff.org/global-healthpolicy/fact-sheet/the-global-hivaids-epidemi c/2;5211/11/2019.

5 WHO. Ethiopia HIV Country Profile. 2016.

6 Tamaryn L, et al. A conceptual framework for understanding HIV risk behavior in the context of supporting fertility goals among HIV sero discordant couples. Reprod Health Matters. 2012;18.

7 Newell ML, H B. Child mortality and HIV infection in Africa: a review. AIDS. 2004;18 (suppl 2):s27-34.

8 Floridia M, T E, Masuelli G, et al. Rate, correlates and outcomes of repeat pregnancy in HIV-infected women. HIV Med. 2017:18.

9 Chen JL, K P, R C, Kanouse DE, et al. Fertility desires and intentions of HIV positive men and women. Fam Plann Perspect. 2001;33.

10 a.T.R.S. N ML. Vertical transmission of HIV-1 infection Trop Med Hygiene. 2000:94

11 Meseret Maru, S A, Alemayehu Bekele. Incidence and predictors of pregnancy among Wome on ART in Debre Markos referral hospital, Northwest Ethiopia: a five-year retrospective cohort study. AIDS Res Treat. 2017:1-8, 2017.

Not Applicable. 
12 Yoo Hyunsuk, L J, Yim Jae-Joon, et al. Effect of the number of pregnancies on mortality risk in HIV-infected women: a prospective cohort study in rural KwaZuluNatal, South Africa. AIDS Behav. 2018.Dec 22;(12):3971-3980.

13 Calvert C, C R. The contribution of HIV to pregnancy related mortality: a systematic review and meta-analysis. AIDS. 2013;27:1631-1639.

14 Tamil Kendall, Isabella D. Eliminating preventable HIV-related maternal mortality in sub-saharan Africa: what do we need to know. Res Prior HIV Maternal Health. 2014; 67:250-258, 2014. December 1.

15 UNAIDS. Global Plan towards the Elimination of New HIV Infections Among Children by 2015 and Keeping Their Mothers Alive 2011-2015. 2011.

16 UNAIDS. A Progress Report on the Global Plan towards the Elimination of New HIV Infections Among Children by 2015 and Keeping Their Mothers Alive. 2012.

17 Menberu G, Alemseged Fessehaye a, et al. Factors affecting fertility decisions of married men and women living with HIV in South Wollo Zone, Northeast Ethiopia. Ethiopia. J Health Dev. 2010;24.

18 Maru Meseret, S A, Alemayehu Bekele. Incidence and predictors of pregnancy among Wome on ART in Debre Markos referral hospital, Northwest Ethiopia: a five-year retrospective cohort study. AIDS Res Treat. 2017:1-8, 2017.

19 Hyunsuk Yoo JL, Yim Jae-Joon, et al. Effect of the number of pregnancies on mortality risk in HIV-infected women: a prospective cohort study in rural KwaZuluNatal, South Africa. AIDS Behav. 2018.Dec 22;(12):3971-3980.

20 Nancy Smee AKS, Stranix-Chibanda Lynda, et al. Factors associated with repeat pregnancy among women in an area of high HIV prevalence in Zimbabwe. Lynda Stranix-Chibanda. 2011;(3):222-229.

21 Regis Kreitchmann VM, Paz Adriana Aparecida, et al. Repeat pregnancy in women with HIV infection in Latin America and the Caribbean. AIDS Care. 2015;27(10): 1289-1297.

22 Akelo V, McLellan-Lemal E, Toledo L, et al. Determinants and experiences of repeat pregnancy among HIV-positive Kenyan women-a mixed- methods analysis. PLoS One. 2015;10(6).

23 Clare E French, Cortina-Borja Mario, Thorne Claire, Tookey PA. Incidence, patterns, and predictors of repeat pregnancies among HIV-infected women in the United
Kingdom and Ireland,1990-2009. J Acquir Immune Defic Syndr. 2012 March 1;59(3): $287-293$.

24 Gonlez R, Rupérez M, Sevene E, et al. Effects of HIV infection on maternal and neonatal health in southern Mozambique: a prospective cohort study after a decade of antiretroviral drugs roll out. PLoS One. 2017;12(6).

25 Lathrop E, DJ J, D I. HIV and maternal mortality. Int J Gynecol Obstet. 2014. November;127(2):213-215.

26 Maria DB. Safe abortion for HIV-positive women with unwanted pregnancy: a reproductive right. Reprod Health Matters. 2003;11(22):152-161.

27 Federal Minster of Health (FMOH). Ethiopia-health-system-transformation-plan. 2015.

28 Jane Kabami ET, Biraro Sam, Bajunirwe Francis. Increasing incidence of pregnancy among women receiving HIV care and treatment at a large urban facility in western Uganda. Reprod Health. 2014;6:11.

29 Akelo V, McLellan-Lemal E, Toledo L, et al. Determinants and experiences of repeat pregnancy among HIV-positive Kenyan women-a mixed- methods analysis. PLoS One. 2015;10, 10(7).

30 Regis Kreitchmann AAP, et al. Repeat pregnancy in women with HIV infection in Latin America and the Caribbean. AIDS Care. 2015;27(10):1289-1297.

31 Mohammed F A. Determinants of desire for children among HIV-positive women in the Afar region,Ethiopia: case control study. PLoS One. 2016;11(3).

32 Friedman RK, b F, et al. Pregnancy rates and predictors in women with HIV/AIDS in Rio de Janeiro, Southeastern Brazil. Pregn HIV/AIDS Women. 2011;45(2):373-381.

33 Curtis CC. Meeting health care needs of women experiencing complications of miscarriage and unsafe abortion: USAID's postabortion care program. J Midwifery Wom Health. 2007;52(4):368-375.

34 Moyo W, Mbizvo MT. Desire for a future pregnancy among women in Zimbabwe in relation to their self-perceived risk of HIV infection, child mortality, and spontaneous abortion. AIDS Behav. 2004;8(1):9-15.

35 Rou H, V I, Djohan G, et al. Contraceptive use and incidence of pregnancy among women after HIV testing in Abidjan, Ivory Coast. Epidemiol Sante Publique. 2009;57 (2):77-86.

36 Atul kotwal, yadav Arun kumar, et al. Knonwledge of Anti-retroviral Therapy among people living with HIV/AIDS. Mar Med Soc volune. 2018;20(1):23-26. 